\title{
Acute Toxicity of Ampicillin to Clarias Gariepinus (Burchell, 1822) Juveniles
}

\author{
Sogbesan $\mathrm{OA}^{*}$ and Aji AM \\ Department of Fisheries, Modibbo Adama University of Technology, Yola
}

Submission: March 15, 2017; Published: May 05, 2017

*Corresponding author: Sogbesan OA, Department of Fisheries, Modibbo Adama University of Technology, Yola, Tel: +2348161518298;

Email:sokayfish@mautech.edu.ng

\begin{abstract}
The research was designed to determine the behavioural responses and acute toxicity of different concentrations of Ampicillin to Clarias gariepinus Juveniles in an indoor experiment. The lethal examination lasted for 96 hours using $0.00 \mathrm{mg} / \mathrm{L}, 10.00 \mathrm{mg} / \mathrm{L}, 20.00 \mathrm{mg} / \mathrm{L}$ and $30.00 \mathrm{mg} / \mathrm{L}$ respectively in a rectangular glass tanks, aerated and stocked at fifteen fish per tank. The behavioural, physical, mortality and water parameters were observed and $\mathrm{LC}_{50}$ determined using probit value. The results indicated that fish exposed to ampicillin showed agitated swimming, air gulping, loss of equilibrium and haemorrhage within the 96hours exposure. The mortality recorded increased according to the increase in the exposure duration and concentrations. $\mathrm{The}_{\mathrm{LC}}=13.80 \mathrm{mg} / \mathrm{L}$ and safety level $=1.38 \mathrm{mg} / \mathrm{L}$ while a prediction equation of $\mathrm{Y}=$ $0.0783+4.3294 \mathrm{X}, \mathrm{R}_{2}=0.993 \mathrm{p}<0.05$ was recorded for Ampicillin. Ampicillin is considered more toxic than all the three antibiotics and should be administered with caution.
\end{abstract}

Keywords: Clarias gariepinus; Ampicillin; Behavioural responses; Acute toxicity; Safety level

\section{Introduction}

Antimicrobial agents can be defined as substances that have the capacity to kill or inhibit the growth of microorganisms such as bacteria, fungi and virus [1]. After their formal discovery by Fleming in 1928, antibiotics have become essential drugs for human and animal health and welfare. Antibiotics can be derived from natural sources or have synthetic origins. They should be safe (non-toxic) to the host, allowing their use as chemotherapeutic agents for the treatment of bacterial infectious diseases. The production of good and healthy fish seeds forms the bedrock of aquaculture [2]. Common mortalities in fish hatcheries due to negative interactions between fish and pathogenic bacteria, may have called for usage of Ampicillin to control and treat the fry and fingerlings [3]. The need to establish the optimum dosage of this antibiotic becomes imperative to ensure the production of healthy fish seeds and safety for man who is the major consumer.

One of the priorities of aquaculture is to increase production and growth rates of fish that will meet the demand of the increasing human population according to FAO [4]. In order to sustain this priority, there is a need to determine as well as establish the optimum and lethal doses of drugs and antibiotics used in fish hatcheries to treat and control pathogenic organisms and also in raising fish to table size [5]. FAO [4] revealed that the contributions of aquaculture can only be fully realized and sustained if a number of issues including the production and supply of good and healthy fish seeds are properly addresses and ensured.

Ampicillin is frequently administered antibiotics to the fish either through the water or included in the fish feed [6] as drug. Most of the fish farmers not aware of the withdrawal period for the antibiotics nor the concentration to administer as well as its potential hazard to humans [6]. The unregulated use of antibiotics in fish farms continues to skyrocket till date. In many countries, farmed fish and shrimps are produced in crowded facilities with inadequate or non-existent regulation of antibiotic use. Efforts are slowly underway to set standards and procedures to detect risk-laden contamination [7]. Bolorunduro et al. [8] has documented that majority of Nigeria Fish farmers had no knowledge of any ethno-veterinary practices (EVP) in fish health management and administration of drugs including antimicrobial. Hence this study is aimed investigating the acute effect of exposing Clarias gariepinus to different concentrations of Ampicillin. 


\section{Materials and Methods}

\section{Experimental location}

The Experimental site was located in Adamawa State of Nigeria, in Fisheries Laboratory inside Modibbo Adama University of Technology, Yola. Adamawa State is located in the northeastern part of Nigeria with a population of 3,737,223 people and land mass of $36,917 \mathrm{~m}^{2}$ Yola. Adamawa State lies between latitudes 7-11N of the Equator and longitudes 11-14 E of the Greenwich Meridian.

\section{Experimental design}

A completely randomized design was used in which the antibiotics concentration was included at equal interval and all fish exposed at the same duration to one antibiotic at an exposure. The selected experimental animals (Juveniles of catfish) are of the same age group.

\section{Experimental procedure}

The experiment is in two phases. The first phase is an Acute or Lethal studies which lasted for 96 hours and the second phase is the sub-lethal indoor experiment that lasted for twelve weeks.

\section{Determination of Concentration of Chemicals}

Ampicillin was used during lethal concentration test on Clarias gariepinus fingerlings. A pilot studies to determined the maximum concentration that will not produce death and the maximum concentration that will produced $100 \%$ death was carried out and in between these concentration values were selected for lethal studies [9].

\section{Lethal experiment}

Two hundred (200) Juveniles of Clarias gariepinus were obtained from Emma farm, Yola. and transported to the laboratory in 50 litres Jerican. They were acclimatized for seven days. The desired Ampicillin concentrations were measured and introduced in to the plastic tank containing ten (10) litres of water each, control had $0.00 \mathrm{mg} / \mathrm{L}, 10 \mathrm{mg} / \mathrm{L}, 20 \mathrm{mg} / \mathrm{L}$ and $30 \mathrm{mg} / \mathrm{L}$ respectively. They were randomly stocked at the rate of fifteen (15) Juveniles per rectangular glass tanks of $50 \mathrm{~cm} \mathrm{x}$ $32 \mathrm{~cm} \times 90 \mathrm{~cm}$. The fish were observed for physical appearances, behavioural and mortality for 24,48, 72 and 96 hours respectively. During the lethal study, physicochemical parameters of water, such as Dissolved Oxygen, $\mathrm{pH}$, Temperature and Alkalinity were measured following the methods described by American Public Health Association - APHA (1985).

The lethal concentrations were determined using the probit values and its relationship with logarithm of the concentrations of Ampicillin [10].

\section{Behavioural and physical response}

The fish behaviour in the experimental set up and condition were observed during lethal studies, observations of the behaviour were carried out at interval of 24.48,72 and 96 hours respectively. The behaviour of the fish toward air gulping were observed and recorded. The appearance of the skin bloody were observed for hemorrhagic response and recorded. These were scored according to Mallum [10] method.

\section{Statistical Analysis}

Data generated were treated with descriptive statistic to determine the mean. All means were analyzed for significance difference at $(\mathrm{p}<0.05)$ using Analysis of variance (ANOVA). Probit analysis was also adopted and regression to determine the $\mathrm{LC}_{50}$ of each of the Antibiotics. Correlation Coefficient (r) was used to determine the association between the various parameters.

\section{Results}

Table 1: Behaviour response of Clarias gariepinus Juveniles Expose to Different Concentrations of Ampicillin (mg/L) For 96 hours.

\begin{tabular}{|c|c|c|c|c|}
\hline $\begin{array}{c}\text { Behavioural } \\
\text { Responses }\end{array}$ & $\mathbf{0 . 0 0 \mathbf { m g } / \mathbf { L }}$ & $\begin{array}{c}\mathbf{1 0 . 0 0} \\
\mathbf{m g} / \mathbf{L}\end{array}$ & $\mathbf{2 0 . 0 0 \mathbf { m g } / \mathbf { L }}$ & $\mathbf{3 0 . 0 0 \mathbf { m g } / \mathbf { L }}$ \\
\hline $\begin{array}{c}\text { Agitated } \\
\text { swimming }\end{array}$ & - & 1 & 1 & 1 \\
\hline Air gulping & - & 1 & 1 & 2 \\
\hline $\begin{array}{c}\text { Loss of } \\
\text { equilibrium }\end{array}$ & - & - & 1 & 1 \\
\hline Haemorrhage & - & - & - & 1 \\
\hline
\end{tabular}

Table 1 shows the behaviour response of C. gariepinus exposed to Ampicillin. Agitated movement occurred to all the concentration from $10.00 \mathrm{mg} / \mathrm{L}$ to $30.00 \mathrm{mg} / \mathrm{L}$. The higher the dosage the more Agitated movement. Loss of equilibrium also occurred in the higher concentrations. Air gulping occurred higher in the highest concentration, but occurred in all the concentration. Haemorrhage can only be seen in the highest concentration, blood seen on the gill.

The temperature and $\mathrm{pH}$ reduces with increase in Ampicillin concentrations while the Alkalinity increases. There is no significant difference $(p>0.05)$ between these parameters values within the concentrations as shown in Table 2. All the data in the same column are not significantly different ( $p>0.05)$.

Table 2: Physicochemical Parameters of Water Monitored During the Exposure of Different Concentrations ( $\mathrm{mg} / \mathrm{L}$ ) of Ampicilln to Clarias gariepinus Juveniles at 96 hours.

\begin{tabular}{|c|c|c|c|c|}
\hline Concentrations & Temperature & $\begin{array}{c}\text { Dissolved } \\
\text { oxygen } \\
\text { (mg/L) }\end{array}$ & $\mathbf{p H}$ & Alkalinity \\
\hline$(\mathrm{mg} / \mathrm{L})$ & $\left({ }^{\circ} \mathrm{C}\right)$ & & & $(\mathrm{ppm})$ \\
\hline 0 & $27.26^{\mathrm{a}}$ & $6.4^{\mathrm{a}}$ & $5.6^{\mathrm{a}}$ & $131^{\mathrm{a}}$ \\
\hline 10 & $27.24^{\mathrm{a}}$ & $6.2^{\mathrm{a}}$ & $5.4^{\mathrm{a}}$ & $132^{\mathrm{a}}$ \\
\hline 20 & $27.22^{\mathrm{a}}$ & $6.2^{\mathrm{a}}$ & $5.2^{\mathrm{a}}$ & $134^{\mathrm{a}}$ \\
\hline 30 & $27.20^{\mathrm{a}}$ & $6.1^{\mathrm{a}}$ & $5.2^{\mathrm{a}}$ & $136^{\mathrm{a}}$ \\
\hline
\end{tabular}


Fisheries and Oceanography Open Access Journal

Table 3: Mortality of Clarias gariepinus Juveniles Expose to Ampicillin at Different Concentration for 96 hours.

\begin{tabular}{|c|c|c|c|c|c|c|c|c|c|c|c|}
\hline \multirow{2}{*}{$\begin{array}{c}\text { Concentrations } \\
\mathrm{mg} / \mathrm{L}\end{array}$} & \multicolumn{9}{|c|}{ Exposure period in hours } & \multirow{2}{*}{$\begin{array}{c}\text { Total } \\
\text { Mortality }\end{array}$} & \multirow{2}{*}{ Mortality\% } \\
\hline & 0 & 12 & 24 & 36 & 48 & 60 & 72 & 84 & 96 & & \\
\hline 0 & - & - & - & - & - & - & - & - & - & 0 & 0 \\
\hline 10 & - & - & - & - & - & 1 & 1 & 2 & 2 & 6 & 40 \\
\hline 20 & - & - & 1 & - & 2 & 1 & 2 & 2 & 2 & 10 & 66.67 \\
\hline 30 & - & - & 3 & 1 & 2 & 1 & 3 & 2 & 2 & 14 & 93.33 \\
\hline
\end{tabular}

The result of toxicity showing mean mortality concentration of Ampicillin at various concentration, mortality occurred in all treatment except in the control. The mean mortality recorded at 96 hours for C. gariepinus juveniles expose to various concentration of Ampicillin varies as shown in Table 3. The mortality increase as increase in concentration, $10 \mathrm{mg} / \mathrm{L}$ had
$40 \%, 20.00 \mathrm{mg} / \mathrm{L}$ had $66.67 \%$ while $30.00 \mathrm{mg} / \mathrm{L}$ had $93.33 \%$ mortality respectively.

The Table 4 contained information on the probit values that ranged from 4.75 to 6.28 while on Figure 1 , the $\mathrm{LC} 50=13.80 \mathrm{mg} / \mathrm{L}$ and safety level $=1.38 \mathrm{mg} / \mathrm{L}$ while a prediction equation of $\mathrm{Y}=0.0783+4.3294 \mathrm{X} 2=0.993 \mathrm{p}<0.05$ are shown.

Table 4: Probit Value of Clarias gariepinus Juveniles Expose to Ampicillin at 96 hours.

\begin{tabular}{|c|c|c|c|c|c|}
\hline Concentration $\mathbf{~ g} / \mathbf{L}$ & Log concentration & Total fish expose & No of fish death & \% of fish death & Probit value \\
\hline 0 & 0 & 15 & 0 & 0 & 0 \\
\hline 10 & 1 & 15 & 6 & 40 & 4.75 \\
\hline 20 & 1.301 & 15 & 10 & 66.67 & 5.44 \\
\hline 30 & 1.4771 & 15 & 14 & 93.33 & 6.48 \\
\hline
\end{tabular}

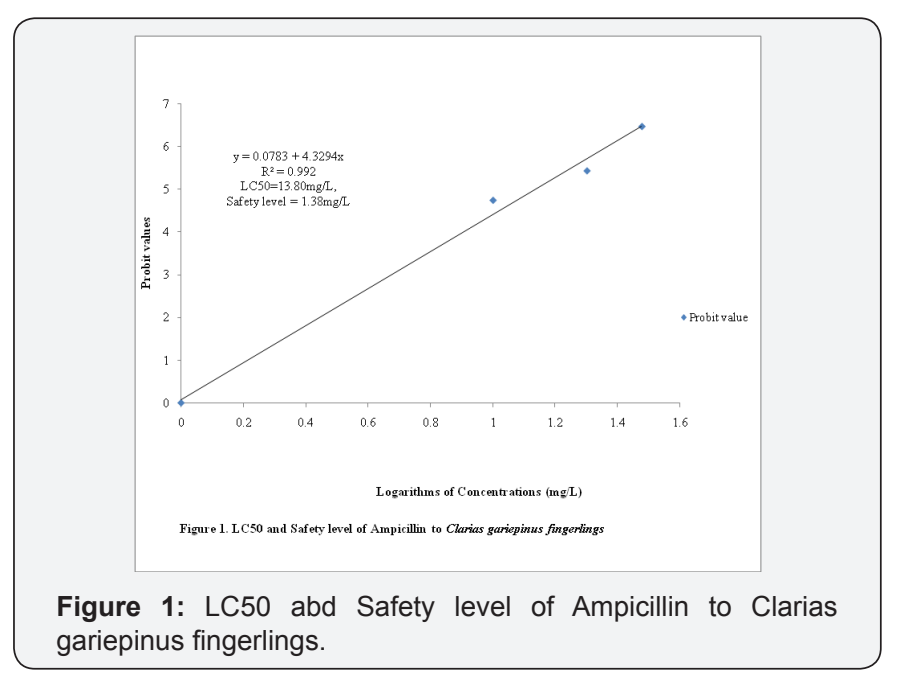

\section{Discussion}

The behavioural and physical responses observed in fish exposed to Ampicillin, Chloraphenicol and Tetracycline were agitated swimming, air gulping, loss of equilibrium and haemorrhage. These responses have also been reported in fish exposed to other different forms of toxicant. The fact that there were variations in the scoring especially at higher concentrations compared to the control its an indication that these antibiotics are toxic to the fish at higher concentrations. Ali et al. [4] observed this while presenting various reasons why drugs including antibiotics are used on fish farm. Such behavioural responses have been reported when fish are also exposed to other chemicals or toxins [11-13]. The loss of balance and direction in the tested organisms, uncoordinated swimming and haemorrhage could be exhibited to a nervous reaction of the fish to the toxicant. The air gulping behavior exhibited by the fish may be as a result of respiratory impairment due to effect of toxicant on the gills. The inability of the gills surface to actively carry out gaseous exchange might be responsible for the recorded mortalities which are significantly different $(\mathrm{p}<0.05)$ in relation to each of the concentrations. Comparatively, the fish exhibited all the behavioural in each of the antibiotics although some concentrations were scored higher than the other which indicated the potency variations in the antibiotics used for this experiment. Behaviorally, the mild responses are from tetracycline to chloraphenicol and ampicillin. This variation corroborate with the reports of Idowu et al. [14], Adeyemo, Ayere [15] and Tittlemier et al. [16].

The water physicochemical parameters were negatively affected as seen from the experiment. The water quality parameters in the extract concentrations did not vary significantly $(p<0.05)$ from what was obtained in the control. Similar observation was reported by Akinwande et al. [12] and Dan-Ologe and Sogbesan [11] when fish were exposed to different concentrations of toxicants. The reduction in dissolved oxygen recorded in this experiment coupled with increase in the alkalinity as the concentrations of each of these antibiotic increases could be attributed to chemical effect of the antibiotics and could have contributed to mortality recorded in the treatments with each of these antibiotics.

The inability of the gills to carry out gaseous exchange effectively could have been responsible for the mortalities recorded which is significantly different $(\mathrm{p}<0.05)$ and directly proportional to the exposure concentrations and period for all the antibiotics. The increase in mortality reported in all 
the antibiotics exposure was due to impairment of normal metabolism by inhibitory effects of the antibiotics which could produce digitalis-like action that may result into arrhythmia, loss of normal heart beat rhythm leading to serious disorder and severe cases may be fatal resulting to death [17] as also seen in all the concentrations tested. It is known that antibiotics and chemotherapeutics can evoke acute toxic effects in animals [18] which has been shown from the results obtained from this study[19].

This $96 \mathrm{hr}$ bioassay justifies the fact that in aquaculture, antibiotics at therapeutic levels are frequently administered for short periods of time via the oral route to groups of fish that share tanks or cages. The LC50 obtained for this short term exposure is indicative of the other effect that the antibiotics even though seen as therapeutic can have on exposed fish [20].

\section{References}

1. Jaime R, Carme GF, Paola N (2012) Antibiotics in Aquaculture; Use, Abuse and Alternatives. Institute for Nutrition and Food Technology, Chile, South Africa.

2. Edward AA, Ladu BMB, Elihu A (2010) Growth, Survival and Production Economics of Clarias gariepinus fingerlings at different Stocking Densities in Concrete Tanks. African Journal of General Agriculture 6(2): 59-66.

3. Cabello FC (2006) Heavy use of prophylactic antibiotics in aquaculture: a growing problem for Human and animal health and for the environment. Environ Microbiol 8(7): 1137-1144.

4. FAO (2014) State of World Fisheries and Aquaculture. Fisheries and Aquaculture Department

of the United Nations, Rome, Italy.

5. Ali MM, Rahman A, Hossain BM, Rahman H (2014) Aquaculture drug used for fish and shellfish Health Management on the Southwestern Bangladesh. Asian Journal of Biological Science 7(5): 225-232.

6. Isaac 00, Afisu B (2013) Antibiotic Usage and Oxytetracycline Residue in African Catfish (Clarias gariepinus in Ibadan, Nigeria). World Journal of Fish and Marine Sciences 5(3): 302-309.

7. Chamberlain G (2002) Food Safety First. Global Aquaculture Advocate 5(1): 2-3.

8. Bolorunduro PI, Jegede OC, Annatte AI (2005) Ethno-Veterinary
Practices in Pond Disease Prevention And Control By Fish Farmers In Niger State, Nigeria. Journal of Research in National Development 3(1): $19-23$

9. Sprague JB (1971) Measurement of pollutant Toxicity to Fish part 111 Sublethal Effects and safe concentration. Water Resources 5: 245-266.

10. Mallum SS (2016) Evaluation of toxicity of propanil and dichlovors on African catfish, Clarias gariepinus (Burchell, 1822) and Nile Tilapia, Oreochromis niloticus (Linnaeus, 1758). PhD Thesis Modibbo Adama University of Technology, Yola, US, p.154.

11. Dan-Ologe IA, Sogbesan OA, Fagade SO (2006) Icthyotoxic assessment of water extract from fresh Euphorbia heterophylla (l) plant stem to Barbus occidentalis (Pisces: Cyprinidae) (Boulenger, 1920) Fingerlings. African Scientist 7(2): 87-92.

12. Akinwande AA, Sogbesan OA, Moody FO, Ugwumba AA (2007) Piscicidal potential of mesocarp of neem plant (Azardirachta indica L.) fruit on hybrid, Heteroclarias. J Environ Biol 28(3): 533-536.

13. Sogbesan, Olukayode A, Emmanuel, Yohan'na Ngadina (2015) Survey and Availability of some Piscicidal Plants used by Fishermen in Adamawa state, Nigeria. IOSR Journal of Environmental Science, Toxicology and Food Technology 9(2): 28-31.

14. Idowu TA, HA Adedeji, Sogbesan OA (2017) Fish Disease and Health Management in Aquaculture Production. International Journal of Environmental and Agricultural Science 1(2): 1-6.

15. Adeyemo AO, Ayere SO (2015) Haematological and Behavioural Responses of Oreochromis niloticus exposed to Crude extracts of Raphia hookeri Fruits. Proceeding of $30^{\text {th }}$ FISON Annual Conference. 22-27.

16. Tittlemier SA, Van de Riet J, Burns G, Potter R, Murphy C, et al. (2007) Analysis of veterinary drug residues in fish and shrimp composites collected during the Canadian Total Diet Study, 1993-2004. Food Addit Contam 24(1): 14-20.

17. Oti EE (2003) Acute toxicity of water extract of bark of the Thevetia peruviana to the African Freshwater Catfish, Heteroclarias hybrid fingerlings. Journal of Fish Technology 2: 124-130.

18. Rijkers GT, Teunissen AG, Van Oosterom R, Van Muiswinkel WB (1980) The immune system of cyprinid fish. The immunosuppressive effect of the antibiotic oxytetracycline in carp (cyprinus carpio l.). Aquaculture 19: $177-189$.

19. Akinbowale OL, Peng H, Barton MD (2006) Antimicrobial resistance in bacteria isolated from aquaculture sources in Australia. J Appl Microbiol 100(5): 1103-1113.

20. Martin B (1973) The use of antibiotics in cattle practice. Vet Rec 92(5): 123.

\section{Your next submission with Juniper Publishers} will reach you the below assets

- Quality Editorial service

- Swift Peer Review

- Reprints availability

- E-prints Service

- Manuscript Podcast for convenient understanding

- Global attainment for your research

- Manuscript accessibility in different formats

( Pdf, E-pub, Full Text, Audio)

- Unceasing customer service

Track the below URL for one-step submission https://juniperpublishers.com/online-submission.php 